\title{
Curcumin inhibits invasive capabilities through epithelial mesenchymal transition in breast cancer cell lines
}

\author{
MARCELA GALLARDO $^{1}$ and GLORIA M. CALAF ${ }^{1,2}$ \\ ${ }^{1}$ Instituto de Alta Investigación, Universidad de Tarapacá, Arica, Chile; \\ ${ }^{2}$ Center for Radiological Research, Columbia University Medical Center, New York, NY, USA
}

Received January 29, 2016; Accepted March 22, 2016

DOI: $10.3892 /$ ijo.2016.3598

\begin{abstract}
Curcumin (diferuloyl methane) is an antioxidant that exerts antiproliferative and apoptotic effects and has anti-invasive and anti-metastatic properties. Evidence strongly implicates that epithelial-mesenchymal transition (EMT) is involved in malignant progression affecting genes such as Slug, AXL and Twist1. These genes are abnormally expressed in many tumors and favor metastasis. The purpose of this study was to determine the potential effect of curcumin on EMT, migration and invasion. Triple-positive and triple-negative breast cancer cell lines for estrogen receptor (ER), progesterone receptor (PgR) and HER/neu were used: i) MCF-10F, a normal immortalized breast epithelial cell line (negative), ii) Tumor2, a malignant and tumorigenic cell line (positive) derived from Alpha5 cell line injected into the immunologically depressed mice and transformed by $60 / 60 \mathrm{cGy}$ doses of high LET (linear energy transfer) $\alpha$ particles $(150 \mathrm{keV} / \mu \mathrm{m})$ of radiation and estrogen, and iii) a commercially available MDA-MB-231 (negative). The effect of curcumin ( $30 \mu \mathrm{M}$ for $48 \mathrm{~h})$ was evaluated on expression of EMT-related genes by RT-qPCR. Results showed that curcumin decreased $E$-cadherin, $N$-cadherin, $\beta$-catenin, Slug, AXL, Twist1, Vimentin and Fibronectin protein expression, independently of the positivity of the markers in the cell lines. Curcumin also decreased migration and invasive capabilities in comparison to their own controls. It can be concluded that curcumin influenced biochemical changes associated with EMT-related genes that seems to promote such transition and are at the core of several signaling pathways that mediate the transition. Thus, it can be suggested that curcumin is able to prevent or delay cancer progression through the interruption of this process.
\end{abstract}

Correspondence to: Dr Gloria M. Calaf, Instituto de Alta Investigación, Universidad de Tarapacá, Calle Antofagasta \#1520, Arica, Chile

E-mail: gmc24@columbia.edu

Key words: curcumin, epithelial-mesenchymal transition, breast cancer cell lines

\section{Introduction}

Breast cancer is the dominant cause of death in women worldwide and it is the most common cancer in big city areas (1). Breast cancer in its advanced-stage has been related to the degree of metastasis (2). The process of metastasis seems to be regulated by a variety of gene products and EMT has been recognized as a fundamental process of embryogenesis, it is an important event in the metastatic cascade where the cells acquire migratory, and invasive capabilities (3).

Curcumin, an effective component of the spice turmeric (Curcuma longa) and a dietary chemopreventive agent $(4,5)$, has been shown to resist initiation of carcinogenesis, modulation of cell survival, induction of apoptosis, inhibition of angiogenesis and induce anti-invasive and anti-metastatic effects (6).

Cadherins are cell adhesion molecules fundamental in the development of multicellular organisms (7). Among them, $E$-cadherin is essential for epithelial tissue integrity (8) and $N$-cadherin is expressed at gastrulation stage by downregulation of $E$-cadherin and undergoing EMT considered in cells of mesenchymal origin (9). Both establish cell-cell adhesion with their extracellular domains and are connected with catenins at their intracellular domains (10). Both also interact with receptors for growth factors involved in the modulation of signaling pathways, E-cadherin in relation with receptors of epidermal growth factors (11), and $\mathrm{N}$-cadherin with fibroblast growth factor receptors (FGFR) (12). The protein B-catenin plays a role in signaling and cell adhesion $(13,14)$.

SLUG, a member of the SNAI family (15-17) is involved in development of EMT (16), it is an inhibitor of apoptosis (18), and is part of breast and kidney development $(15,16)$. AXL is activated through several mechanisms, as binding of its ligand and dimerization with HER2/neu (19-21). Since AXL is overexpressed in human cancers, it has significant correlation with tumor stage in breast cancer, especially in metastases $(22,24)$. Twist1 is another factor that induces EMT and degradation of extracellular matrix (25-27) by promoting loosening of cell-cell junctions of epithelial cells and becoming invasive (28).

Vimentin is the most important part of the cytoskeletal of the cell along with microtubules and microfilaments (29). Fibronectin exerts multiple effects in vitro and in vivo as a component of the extracellular matrix stimulating proliferation, migration and differentiation (30-33). It activates various 
Table I. Primers for genes selected to develop cDNA probes.

\begin{tabular}{|c|c|c|}
\hline Gene name & Product length $(b p)^{a}$ & Primer sequence ${ }^{\mathrm{b}}$ \\
\hline E-cadherin & 93 & $\begin{array}{l}\text { F: AGTGGGCACAGATGGTGTGA } \\
\text { R: TAGGTGGAGTCCCAGGCGTA }\end{array}$ \\
\hline$N$-cadherin & 67 & $\begin{array}{l}\text { F: TCG ATT GGT TTG ACC ACG G } \\
\text { R: GAC GGT TCG CCA TCC AGA C }\end{array}$ \\
\hline$\beta$-catenin & 94 & $\begin{array}{l}\text { F: GCAGAGTGCTGAAGGTGCTA } \\
\text { R: TCTGTCAGGTGAAGTCCTAAAGC }\end{array}$ \\
\hline Slug & 72 & $\begin{array}{l}\text { F: GACCCTGGTTGCTTCAAGGA } \\
\text { R: TGTTGCAGTGAGGGCAAGAA }\end{array}$ \\
\hline$A X L$ & 121 & $\begin{array}{l}\text { F: GTTTGGAGCTGTGATGGAAGGC } \\
\text { R: CGCTTCACTCAGGAAATCCTCC }\end{array}$ \\
\hline Twistl & 118 & $\begin{array}{l}\text { F: TCCGCGTCCCACTAGCA } \\
\text { R: AGTTATCCAGCTCCAGAGTCTCTAGAC }\end{array}$ \\
\hline Vimentin & 117 & $\begin{array}{l}\text { F: TGTCCAAATCGATGTGGATGTTTC } \\
\text { R: TTGTACCATTCTTCTGCCTCCTG }\end{array}$ \\
\hline Fibronectin & 105 & $\begin{array}{l}\text { F: GGAGGAAGCCGAGGTTTTAAC } \\
\text { R: ACGCTCATAAGTGTCACCCA }\end{array}$ \\
\hline ZEB1 & 141 & $\begin{array}{l}\text { F: GCACAACCAAGTGCAGAAGA } \\
\text { R: GCCTGGTTCAGGAGAAGATG }\end{array}$ \\
\hline$Z E B 2$ & 128 & $\begin{array}{l}\text { F: CAAGAGGCGCAAACAAGC } \\
\text { R: GGTTGGCAATACCGTCATCC }\end{array}$ \\
\hline EZH2 & 84 & $\begin{array}{l}\text { F: CCAAGAGAGCCATCCAGACT } \\
\text { R: CGATGCCGACATACTTCAGG }\end{array}$ \\
\hline STAT3 & 163 & $\begin{array}{l}\text { F: GGTTGGACATGATGCACACTAT } \\
\text { R: AGGGCAGACTCAAGTTTATCAG }\end{array}$ \\
\hline Cyclin D1 & 60 & $\begin{array}{l}\text { F: GTGGCCTCTAAGATGAAGGA } \\
\text { R: GGTGTAGATGCACAGCTTCT }\end{array}$ \\
\hline Notchl & 140 & $\begin{array}{l}\text { F: GAGGCGTGGCAGACTATGC } \\
\text { R: CTTGTACTCCGTCAGCGTGA }\end{array}$ \\
\hline
\end{tabular}

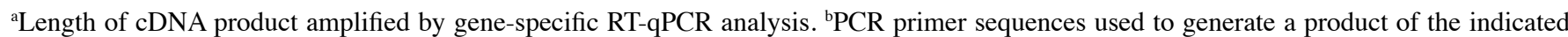
size, listed in $5^{\prime} \rightarrow 3^{\prime}$ orientation. F, forward; R, reverse.

cell surface receptors most notably integrins (34) as well as development of fibrillar structures (35) and activation of various growth factors (36).

An inducer of EMT in cancer metastasis is the ZEB1, a transcription factor that also induces EMT-suppressing microRNA-200s (miR-200s) (37). ZEB2 belongs to the ZEB protein family (38) and it is involved in differentiation $(39,40)$. Enhancer of zeste homolog 2 (EZH2) silences gene transcription by trimethylation of histone H3 (41). It is upregulated in multiple malignancies $(42,43)$, and mediated by silencing tumor suppressor genes (44). It is implicated in transcriptional activation whose mechanism is not known (45-48).

STAT3, member of the family known as signal transducers, is involved in oncogenesis (49). Cyclins have been identified as regulatory subunits and catalytic subunits of cell cycle-regulated kinases. The cyclin/cdk complexes are implicated in the control of mitosis. G1 to $\mathrm{S}$ transition is regulated by Cyclin D since abnormalities involving cyclin D1 deregulate control of the G1-S transition contributing to tumor development $(50,51)$.

Notch proteins are a family of transmembranes with five ligands. Notch signaling is activated in human breast cancer with the accumulation of Notch1 intracellular domain in tissue (52). It has been shown that Notch1 activates Akt and survivin $(53,54)$, and has also been involved in chemoresistance. Increased Notch ligands have been shown to be correlated with poor overall survival in breast cancer patients (55).

Thus, the purpose of this study was to evaluate the effect of curcumin on EMT when a comparison was done between a triple-positive and a triple-negative breast cancer cell lines for $\mathrm{ER}, \mathrm{PgR}$ and Erb-B2 in relation to this process. Curcumin effect was evaluated with triple-negative cell line the immortalized breast epithelial cell line MCF-10F, Tumor2, a triple-positive cell line derived from Alpha5 injected into the nude mice, and MDA-MB231, a triple-negative for the same markers. 
$\mathbf{A}$

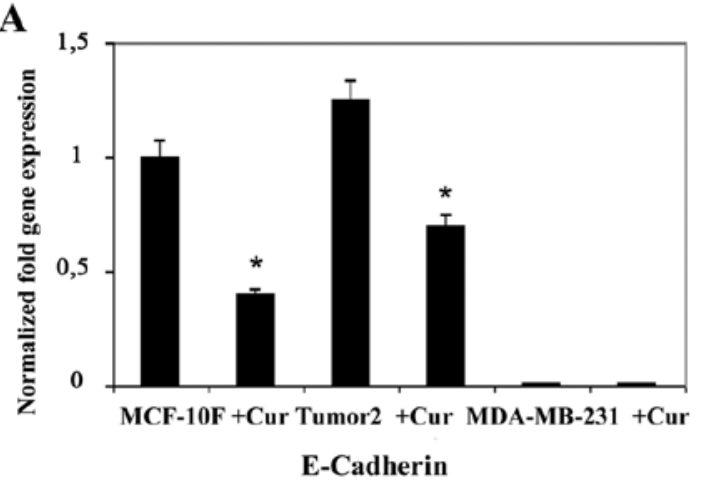

C

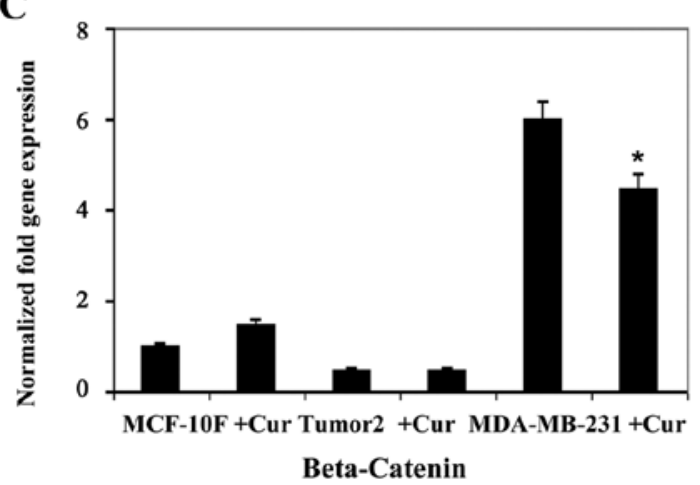

B

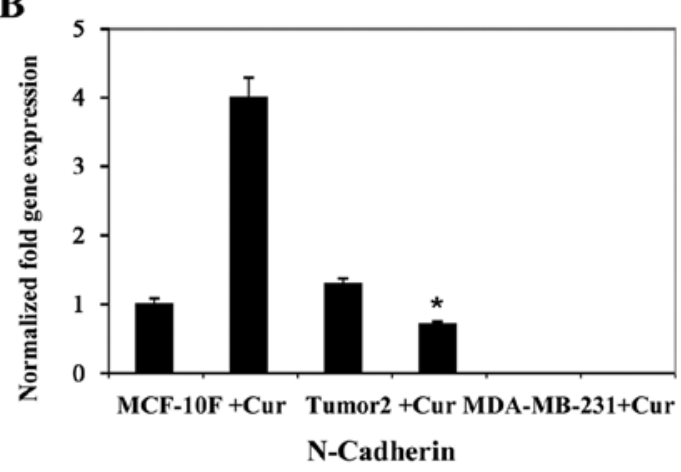

D

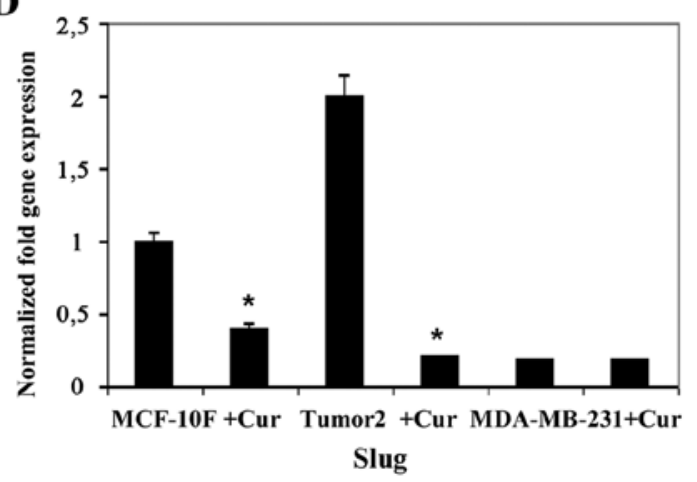

Figure 1. Effect of curcumin on (A) E-cadherin, (B) $N$-cadherin, (C) $\beta$-catenin and (D) Slug gene expression in MCF-10F, Tumor2 and MDA-MB-231 cell lines analyzed by RT-qPCR. Bars represent the mean \pm SEM. ${ }^{* *} \mathrm{P}<0.01$ versus counterpart.

\section{Materials and methods}

Cell cultures and treatment. MCF-10F, Tumor2 and MDA-MB231 human breast cell lines were maintained in Dulbecco's (DMEM; Gibco, USA) supplemented with penicillin $(100 \mathrm{U} / \mathrm{ml})$, streptomycin $(100 \mu \mathrm{g} / \mathrm{ml}), 0.1 \mathrm{mM}$ non-essential amino acids, $0.2 \mathrm{mM}$ glutamine, $1 \mathrm{mM}$ pyruvate, and $10 \%$ heat-inactivated fetal bovine serum and incubated in a $5 \% \mathrm{CO}_{2}$ humidified atmosphere at $37^{\circ} \mathrm{C}$.

RNA extraction and cDNA synthesis. Total RNA was isolated by using TRIzol reagent (Invitrogen Corp., Carlsband, CA, USA) according to the manufacturer's instructions. Total RNA $(2 \mu \mathrm{g})$ was reverse transcribed to cDNA using High Capacity cDNA Reverse Transcription kit (Applied Biosystems, Carlsband, CA, USA) and RNase inhibitor (Applied Biosystems) were used in these studies.

$R T-q P C R$. The cDNA $(2 \mu \mathrm{l})$ was used in $20 \mu \mathrm{l}$ qPCR reaction containing SYBR Green PCR Master Mix (Agilent, La Jolla, CA, USA) and $5 \mu \mathrm{M}$ of each primer for the target genes such as E-cadherin, $N$-cadherin, $\beta$-catenin, Slug, $A X L$, Twist1, Vimentin, Fibronectin, ZEB1, ZEB2, EZH2, STAT3, Cyclin D1, and Notch1. Table I shows the primers for the gene selected to develop cDNA probes. The reaction was performed in a CFX 96 Real-Time PCR (Bio-Rad Laboratories, Hercules, CA, USA) at $95^{\circ} \mathrm{C}$ for $10 \mathrm{~min}$ and 40 cycles of a 2-step program of $95^{\circ} \mathrm{C}$ for $10 \mathrm{sec}$ and $61^{\circ} \mathrm{C}$ for $45 \mathrm{sec}$ when fluorescence-reading occurs. After amplification, $\mathrm{PCR}$ product was monitored through dissociation curve analysis (measure- ment of fluorescence during an increasing heating of $2^{\circ} \mathrm{C} / \mathrm{min}$ from 61 to $95^{\circ} \mathrm{C}$ ). At this step, undesirable DNA contamination (if present) could be detected since primers were designed to encompass an intron. Reactions were performed in triplicate and the threshold of the cycle was obtained using Bio-Rad CFX Manager 2.1 software and the average gene expression was normalized with a reference housekeeping gene $\beta$-actin. Relative expression was a normalized to the average in cells.

Cell migration and invasion assays. The modified Boyden's chambers to analyze migration and invasiveness were used as described (56) (Corning, NY, USA). Cells $\left(3 \times 10^{5}\right)$ in $100 \mu \mathrm{l}$ of medium were used for migration and invasion assays; $8-\mu \mathrm{m}$ membrane pores were pre-coated with $60 \mu \mathrm{l}$ Matrigel matrix gel (BD Biosciences, Grand Island, NY, USA) at least one hour before seeding the cells for upper chambers; $600 \mu 1$ of medium with $10 \%$ FBS was placed in the lower chambers as chemoattractant. Cells treated with $30 \mu \mathrm{M}$ curcumin were cultured for $48 \mathrm{~h}$ in a humidified incubator. Then, the upper chambers were wiped using cotton swabs. The membranes were fixed with $100 \%$ methanol at room temperature for $15 \mathrm{~min}$, visualized and quantified using DAPI. Ten fields of each chamber were photographed (x40 magnification). This experiment was independently repeated two times.

Statistical analysis. Results of gene expression of control and treated group were compared with ANOVA followed by Dunnet's test. The average \pm standard error of the mean was used to express numerical data. A p-value $<0.05$ was considered statistically significant. 
A

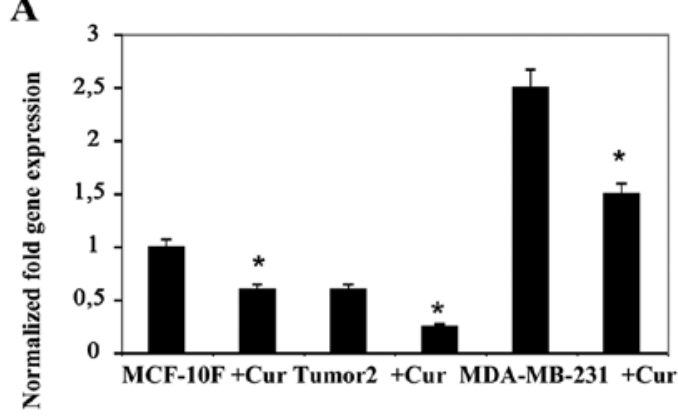

AXL

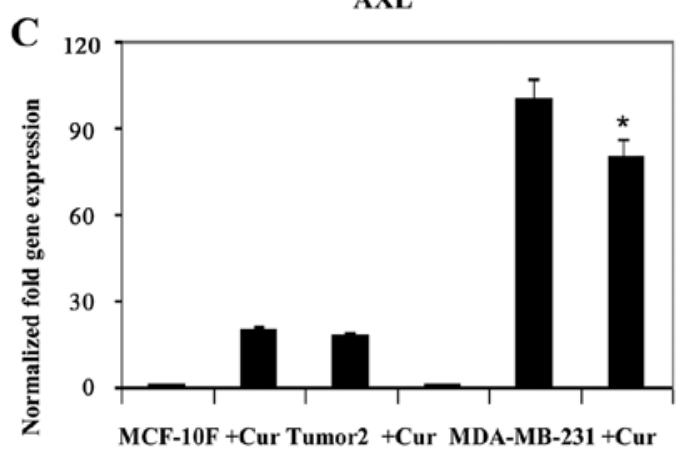

Vimentin

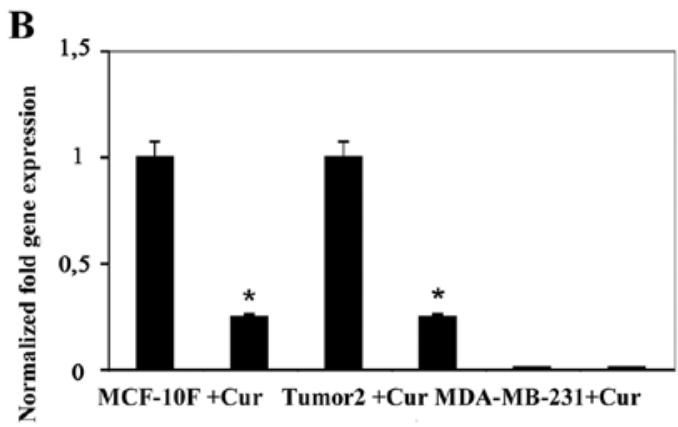

Twist1

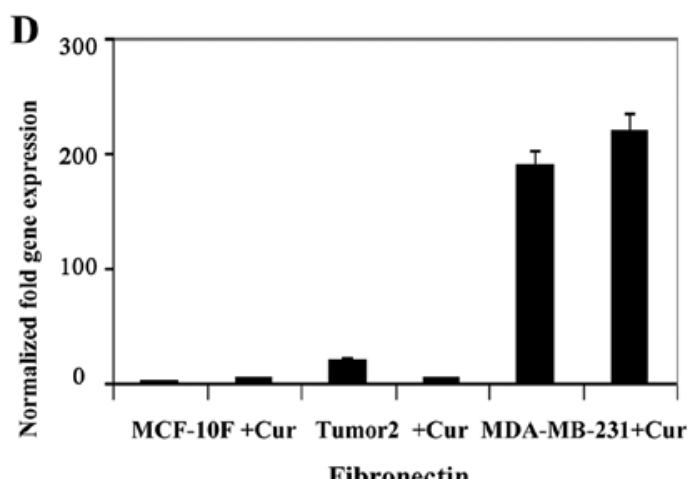

Fibronectin

Figure 2. Effect of curcumin on (A) AXL, (B) Twist1, (C) Vimentin and (D) Fibronectin gene expression in MCF-10F, Tumor2 and MDA-MB-231 cell lines studied by RT-qPCR. Bars represent the mean \pm SEM. ${ }^{* *} \mathrm{P}<0.01$ versus counterpart.

\section{A}

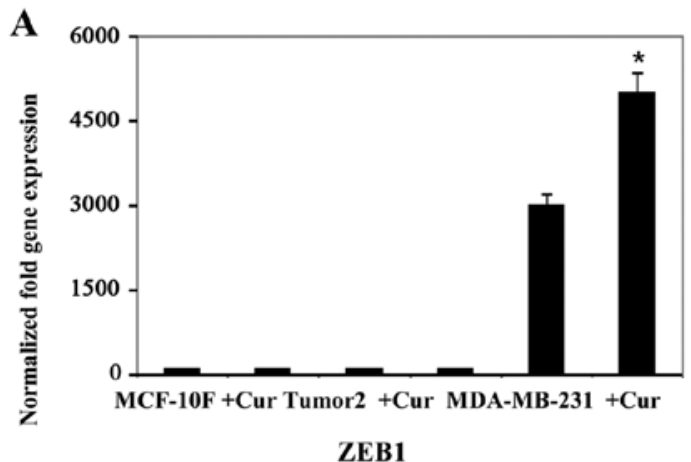

C

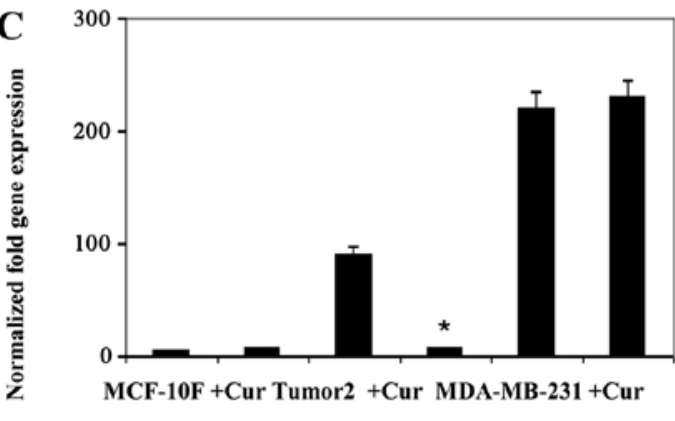

EZH2

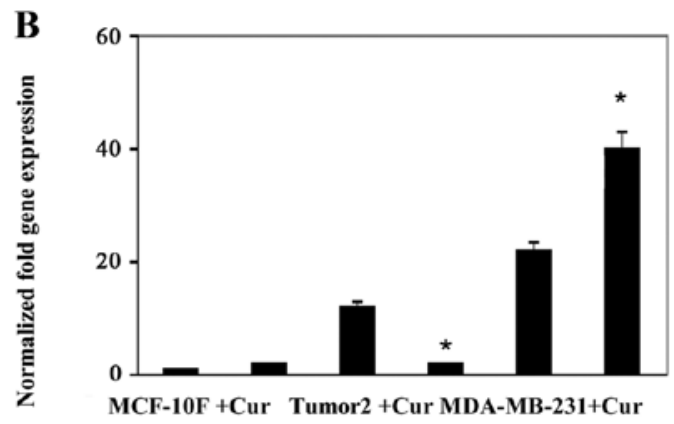

ZEB2

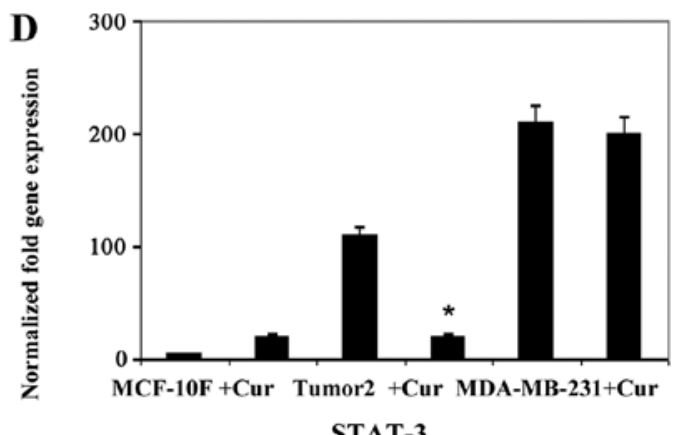

STAT-3

Figure 3. Effect of curcumin on (A) ZEB1, (B) ZEB2, (C) EZH2 and (D) Stat3 gene expression in MCF-10F, Tumor2 and MDA-MB-231 cell lines analyzed by RT-qPCR. Bars represent the mean \pm SEM. ${ }^{* *} \mathrm{P}<0.01$ versus counterpart.

\section{Results}

Effect of curcumin on growth of breast cancer cells in vitro. We analyzed the effect of curcumin on cell proliferation of MCF-10F, Tumor2 and MDA-MB-231 cell lines after $48 \mathrm{~h}$. Graded concentrations of curcumin $(0-70 \mu \mathrm{M} / \mathrm{l})$ were used to determine cell viability by MTT assay. The growth curves showed that cell proliferation was inhibited in a dose-dependent manner by curcumin with inhibition at doses $\geq 30 \mu \mathrm{M} / 1$.

Curcumin inhibits the expression of markers of EMT in breast cancer cells. To confirm the effects of curcumin on EMT, we 
A

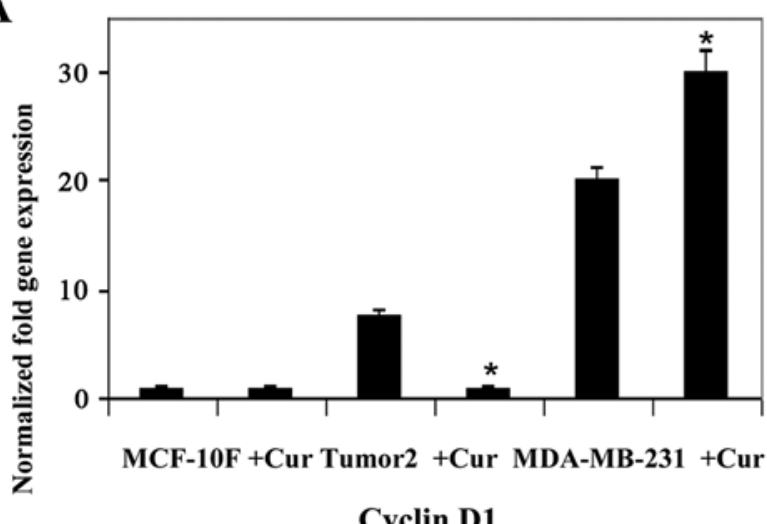

B

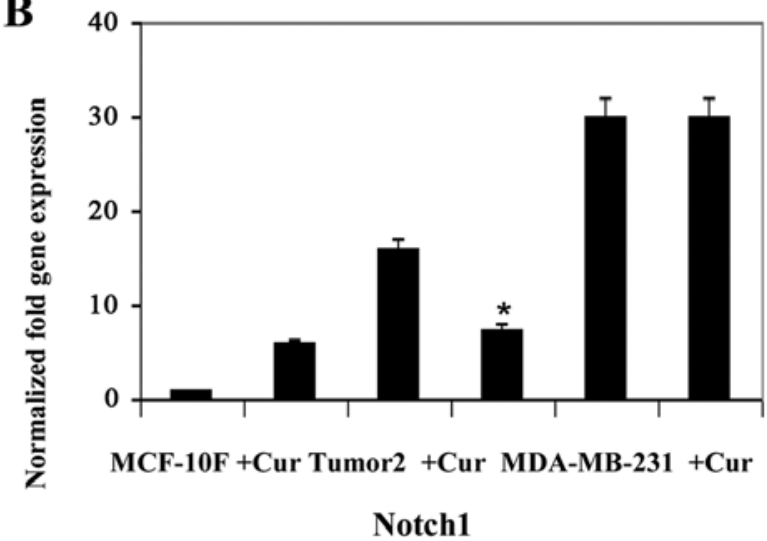

Figure 4. Effect of curcumin on (A) Cyclin D1 and (B) Notch1 gene expression in MCF-10F, Tumor2 and MDA-MB-231 cell lines analyzed by RT-qPCR. Bars represent the mean \pm SEM. ${ }^{* *} \mathrm{P}<0.01$ versus counterpart.

sequentially analyzed gene expression of EMT markers by RT-qPCR analysis. Results indicated that curcumin decreased gene expression of twelve genes, E-Cad, N-Cad, Slug, AXL, Twist1, Vimentin, Fibronectin, ZEB2, EZH2, STAT3, Cyclin D1 and Notch1 in Tumor2 triple-positive for ER, PgR and ErbB2 protein expression (Figs. 1-4). However, curcumin only decreased gene expression of four genes, $\beta$-catenin and Slug (Fig. 1), AXL and Vimentin (Fig. 2) in MDA-MB-231 triple-negative cells for the same markers used in clinic. Curcumin increased gene expression of E-Cad and N-Cad (Fig. 1), ZEB1 (Fig. 3), Cyclin D1 (Fig. 4) in MDA-MB-231 triple-negative. MCF-10F decreased gene expression of four genes, E-Cad, Slug, AXL and Twistl (Fig. 2), and it increased gene expression of eight genes, $\mathrm{N}-\mathrm{Cad}, \beta$-catenin, Vimentin, Fibronectin (Fig. 2), ZEB2, EZH2 and STAT3 (Fig. 3) and Notch1 (Fig. 4).

Effect of curcumin on migration and invasion of breast cancer cells. EMT is associated with metastasis. The motile phenotypes of cells treated with curcumin were evaluated. The number of migratory (Fig. 5) and invasive (Fig. 6) capabilities of cells was significantly reduced in cells after treatment with curcumin. Thus, our study suggested that curcumin could delay cancer progression through its ability to disrupt EMT. It can be concluded that curcumin influenced biochemical changes associated with EMT.

\section{Discussion}

Curcumin has been shown to inhibit carcinogen activation and angiogenesis, modulate cell survival and apoptosis, with anti-invasive and anti-metastatic effects on breast, lung, colon and prostate cancer (57). Curcumin reduced cell proliferation of MCF-10F, Tumor2 and MDA-MB-231 cell lines after $48 \mathrm{~h}$ when cell viability was measured by MTT assay. Cell proliferation was inhibited in a dose-dependent manner with evident inhibition at dose $\geq 30 \mu \mathrm{mol} / \mathrm{l}$ ). Curcumin has demonstrated antioxidant and antiproliferative properties in breast cancer and seems to induce a $\mathrm{G} 2 / \mathrm{M}$ phase arrest (58-60).

EMT has a role in embryonic development and cancer progression, where epithelial cells acquire mesenchymal phenotypes. It reduces cell-to-cell adhesion, loses cell polarity, enhances migratory and invasive capabilities (61); then tumor cells migrate from their site of origin to other tissues activating specific genetic changes (62). During EMT, epithelial cancer cell layers lose polarity, cell-to-cell contact and then undergo a dramatic remodeling of the cytoskeleton. Expression of E-cadherin and $\gamma$-catenin are lost and cells acquire mesenchymal markers such as $\mathrm{N}$-cadherin, vimentin and fibronectin enhancing the ability for cell migration and invasion (63). Once tumor cells migrate they re-express E-cadherin and other epithelial markers through a process that is often referred to as mesenchymal-epithelial transition (MET) (64). Therefore, agents that block or reverse these processes offer a therapeutic strategy to avoid cancer progression. Curcumin can re-establish an epithelial phenotype from mesenchymal cells by blocking EMT-related gene expression.

EMT induction is driven by interplay between tumor environment and cancer cells which mechanisms may activate different transcriptional factors such as Twist, Slug and Snail, through multiple cellular signaling pathways (65-69). Analysis of the expression of EMT-related genes indicated that curcumin decreased gene expression of E-cadherin, Slug, $A X L$ and Twistl in MCF-10F cell line (four genes). While the substance decreased $N$-cadherin, $\beta$-catenin, Slug, $A X L$, Twist1, Vimentin, Fibronectin, ZEB2, EZH2 and STAT3 in Tumor2 (ten genes) and in MDA-MB-231, triple-negative cell lines such as E-cadherin, $N$-cadherin, Twist1, $A X L$ and Fibronectin (five genes) gene expression in comparison to its counterpart. It is important to conclude that EMT was triggered by curcumin in MDA-MB-231 cells since it not only decreased the expression of EMT genes but induced morphological changes and inhibited cell motility and invasiveness.

Curcumin did not induce significant difference in Fibronectin gene expression in MCF-10F or Tumor2. However, curcumin decreased gene expression of AXL, and Fibronectin in MDA-MB-231 cell line. During cancer progression carcinoma cells seem to enter into an EMT program, acquiring features of mesenchymal-like cells that influenced invasiveness (62). Evidence has shown that EMT is involved in malignant progression by inducing genes such as Slug, $A X L$ 
A

\section{Migration}

Control

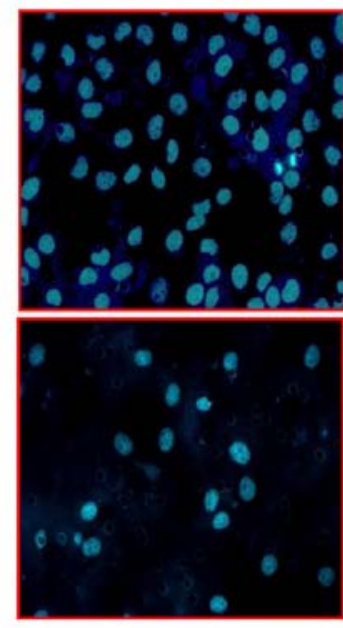

MCF-10F

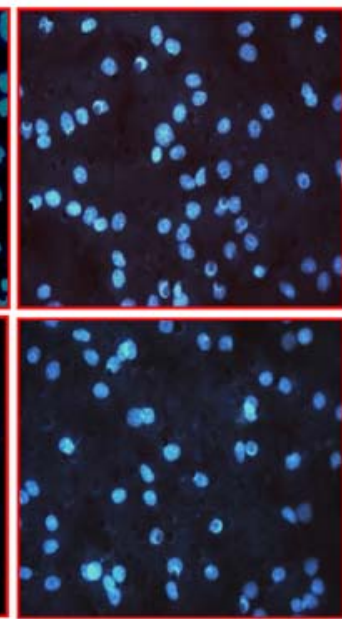

Tumor2

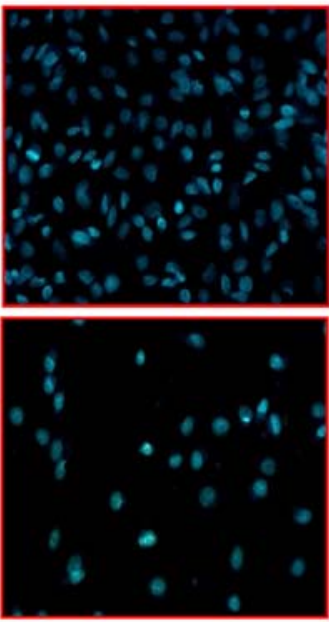

MDA-MB-231

B

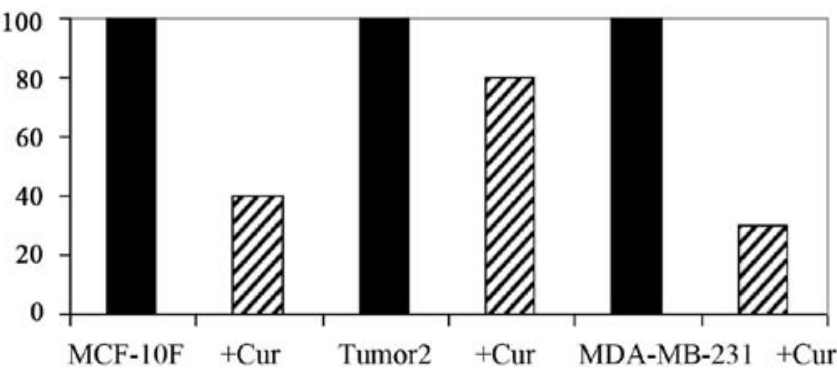

Figure 5. Effect of curcumin on migration in MCF-10F and Tumor2 cell lines analyzed by modified Boyden's chambers. (A) Cell lines were stained with DAPI after curcumin treatment. (B) Graph that represents the relative grade of luminescence of cell lines in relation to migration from $100 \%$ of the counterpart, respectively. Bars represent the mean $\pm \mathrm{SEM} .{ }^{* *} \mathrm{P}<0.01$ versus counterpart.

A

Invasion

Control
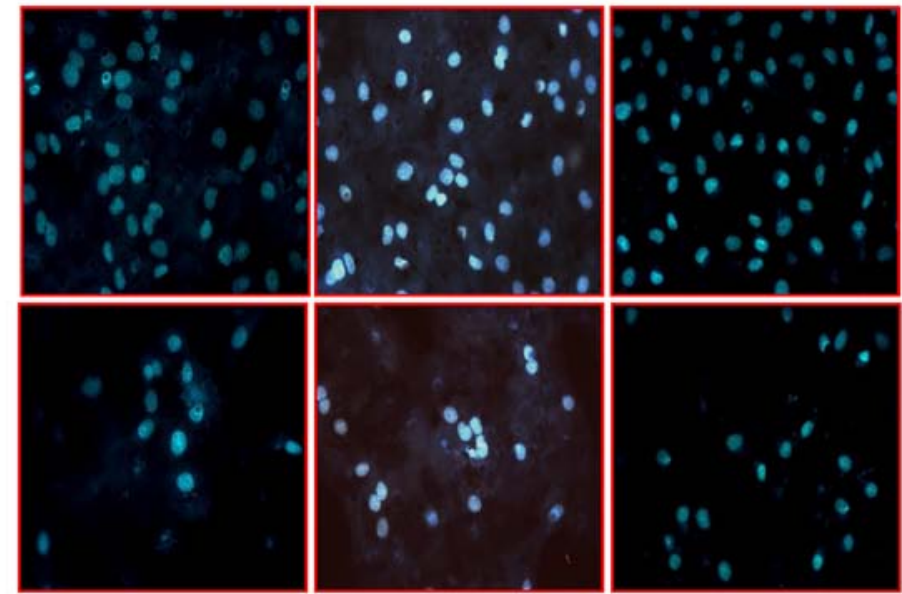

MCF-10F

Tumor2

MDA-MB-231

B

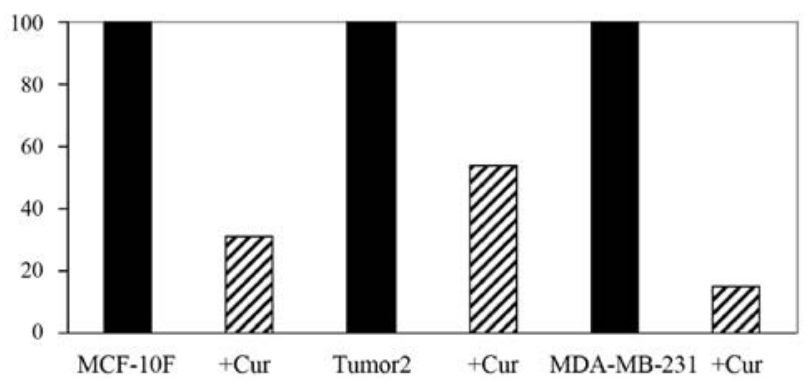

Figure 6. Effect of curcumin on invasion in MCF-10F and Tumor2 cell lines analyzed by modified Boyden's chambers. (A) Cell lines were stained with DAPI after curcumin treatment. (B) Graph that represents the relative grade of luminescence of MCF-10F and Tumor2 cell lines in relation to invasion from 100\% of the counterpart, respectively. Bars represent the mean $\pm \mathrm{SEM} .{ }^{* *} \mathrm{P}<0.01$ versus counterpart. 
and Twistl since such genes are expressed in numerous tumor types favoring the metastatic process.

E-cadherin plays an important role in epithelial cell adhesion and acts as a metastatic suppressor in epithelial carcinomas since loss of E-cadherin is associated with advanced diseases (70). Vimentin is found in mesenchymal cells and its expression has been observed in the progression of EMT, tumor cells that are highly proliferative and invasive (71). E-cadherin and Vimentin are markers of EMT and directly regulated by Slug $(72,73)$ since many preventive agents effectively inhibit EMT by inhibiting Slug transcription factors. In this study curcumin inhibited Slug expression, affecting E-cadherin and vimentin to retard cancer cell invasion and providing new mechanistic bases for therapeutic use in breast cancer patients.

Cyclin D1 gene plays a critical role in breast carcinogenesis. It seems that the antiproliferative effects of curcumin are due to inhibition of Cyclin D1 expression (74). Thus, decreased expression of Cyclin D1 was observed in Tumor2 and MDA-MB-231. Others reported a decrease in the Cyclin D1 protein expression with curcumin treatment (75). Curcumin inhibited the expression of several EMT markers such as $\beta$-catenin and Slug in both Tumor2 and MDA-MB-231. Our data demonstrated the efficacy of curcumin since it reduced Notch1 expression suggesting its antimetastasis function through downregulation of EMT genes and by promoting other genes. It was also found that curcumin inhibited migration and invasion of breast cancer cells. It was reported that curcumin inhibits the migration and invasion of lung (76) and breast (77) cancer cells. These data provide a new perspective on the role of curcumin in the anti-invasive properties of breast cancer cells by its ability to interfere with the EMT process. Most importantly, this study demonstrated and clarified the potential effect of curcumin to inhibit EMT-related gene expression in a triple-positive and a triple-negative cell line.

\section{Acknowledgements}

The technical support of Guiliana Rojas, Georgina Vargas Marchant and Leodán A. Crispin is greatly appreciated. This study was supported by grant support FONDECYT no. 1120006 (G.M.C.) and MINEDUC-UTA (G.M.C.).

\section{References}

1. Beiki O, Hall P, Ekbom A and Moradi T: Breast cancer incidence and case fatality among 4.7 million women in relation to social and ethnic background: A population-based cohort study. Breast Cancer Res 14: R5, 2012.

2. Malfettone A, Saponaro C, Paradiso A, Simone G and Mangia A: Peritumoral vascular invasion and NHERF1 expression define an immunophenotype of grade 2 invasive breast cancer associated with poor prognosis. BMC Cancer 12: 106, 2012.

3. Cowin P and Welch DR: Breast cancer progression: Controversies and consensus in the molecular mechanisms of metastasis and EMT. J Mammary Gland Biol Neoplasia 12: 99-102, 2007.

4. Naithani R, Huma LC, Moriarty RM, McCormick DL and Mehta RG: Comprehensive review of cancer chemopreventive agents evaluated in experimental carcinogenesis models and clinical trials. Curr Med Chem 15: 1044-1071, 2008.

5. Verschoyle RD, Steward WP and Gescher AJ: Putative cancer chemopreventive agents of dietary origin-how safe are they? Nutr Cancer 59: 152-162, 2007.

6. Basnet P and Skalko-Basnet N: Curcumin: An anti-inflammatory molecule from a curry spice on the path to cancer treatment. Molecules 16: 4567-4598, 2011.
7. Takeichi M: Morphogenetic roles of classic cadherins. Curr Opin Cell Biol 7: 619-627, 1995.

8. Kotb AM, Hierholzer A and Kemler R: Replacement of $E$-cadherin by $N$-cadherin in the mammary gland leads to fibrocystic changes and tumor formation. Breast Cancer Res 13: R104, 2011.

9. Radice GL, Rayburn H, Matsunami H, Knudsen KA, Takeichi M and Hynes RO: Developmental defects in mouse embryos lacking N-cadherin. Dev Biol 181: 64-78, 1997.

10. Ozawa M, Baribault H and Kemler R: The cytoplasmic domain of the cell adhesion molecule uvomorulin associates with three independent proteins structurally related in different species. EMBO J 8: 1711-1717, 1989.

11. Hoschuetzky H, Aberle H and Kemler R: Beta-catenin mediates the interaction of the cadherin-catenin complex with epidermal growth factor receptor. J Cell Biol 127: 1375-1380, 1994.

12. Williams EJ, Furness J, Walsh FS and Doherty P: Activation of the FGF receptor underlies neurite outgrowth stimulated by L1, N-CAM, and N-cadherin. Neuron 13: 583-594, 1994.

13. Ilyas M and Tomlinson IP: The interactions of APC, E-cadherin and beta-catenin in tumour development and progression. J Pathol 182: 128-137, 1997.

14. Morin PJ, Sparks AB, Korinek V, Barker N, Clevers H, Vogelstein B and Kinzler KW: Activation of beta-catenin-Tcf signaling in colon cancer by mutations in beta-catenin or APC. Science 275: 1787-1790, 1997.

15. Nieto MA: The snail superfamily of zinc-finger transcription factors. Nat Rev Mol Cell Biol 3: 155-166, 2002.

16. Barrallo-Gimeno A and Nieto MA: The Snail genes as inducers of cell movement and survival: Implications in development and cancer. Development 132: 3151-3161, 2005.

17. Hemavathy K, Guru SC, Harris J, Chen JD and Ip YT: Human Slug is a repressor that localizes to sites of active transcription. Mol Cell Biol 20: 5087-5095, 2000.

18. Wu WS, Heinrichs S, Xu D, Garrison SP, Zambetti GP, Adams JM and Look AT: Slug antagonizes p53-mediated apoptosis of hematopoietic progenitors by repressing puma. Cell 123: 641-653, 2005.

19. O'Bryan JP, Frye RA, Cogswell PC, Neubauer A, Kitch B, Prokop C, Espinosa R III, Le Beau MM, Earp HS and Liu ET: axl, a transforming gene isolated from primary human myeloid leukemia cells, encodes a novel receptor tyrosine kinase. Mol Cell Biol 11: 5016-5031, 1991.

20. Bose R, Molina H, Patterson AS, Bitok JK, Periaswamy B, Bader JS, Pandey A and Cole PA: Phosphoproteomic analysis of Her2/neu signaling and inhibition. Proc Natl Acad Sci USA 103: 9773-9778, 2006.

21. Hafizi S and Dahlbäck B: Gas6 and protein S. Vitamin $\mathrm{K}$-dependent ligands for the Axl receptor tyrosine kinase subfamily. FEBS J 273: 5231-5244, 2006.

22. Hutterer M, Knyazev P, Abate A, Reschke M, Maier H, Stefanova N, Knyazeva T, Barbieri V, Reindl M, Muigg A, et al: Axl and growth arrest-specific gene 6 are frequently overexpressed in human gliomas and predict poor prognosis in patients with glioblastoma multiforme. Clin Cancer Res 14: 130-138, 2008.

23. Li Y, Ye X, Tan C, Hongo JA, Zha J, Liu J, Kallop D, Ludlam MJ and Pei L: Axl as a potential therapeutic target in cancer: Role of Axl in tumor growth, metastasis and angiogenesis. Oncogene 28: 3442-3455, 2009.

24. Zhang YX, Knyazev PG, Cheburkin YV, Sharma K, Knyazev YP, Orfi L, Szabadkai I, Daub H, Kéri G and Ullrich A: AXL is a potential target for therapeutic intervention in breast cancer progression. Cancer Res 68: 1905-1915, 2008.

25. Yang J, Mani SA, Donaher JL, Ramaswamy S, Itzykson RA, Come C, Savagner P, Gitelman I, Richardson A and Weinberg RA: Twist, a master regulator of morphogenesis, plays an essential role in tumor metastasis. Cell 117: 927-939, 2004.

26. Casas E, Kim J, Bendesky A, Ohno-Machado L, Wolfe CJ and Yang J: Snail2 is an essential mediator of Twist1-induced epithelial mesenchymal transition and metastasis. Cancer Res 71: 245-254, 2011.

27. Eckert MA, Lwin TM, Chang AT, Kim J, Danis E, OhnoMachado L and Yang J: Twist1-induced invadopodia formation promotes tumor metastasis. Cancer Cell 19: 372-386, 2011.

28. Low-Marchelli JM, Ardi VC, Vizcarra EA, van Rooijen N, Quigley JP and Yang J: Twist1 induces CCL2 and recruits macrophages to promote angiogenesis. Cancer Res 73: 662-671, 2013.

29. Sommers CL, Skerker JM, Chrysogelos SA, Bosseler M and Gelmann EP: Regulation of vimentin gene transcription in human breast cancer cell lines. Cell Growth Differ 5: 839-846, 1994. 
30. Manabe R, Oh-e N and Sekiguchi K: Alternatively spliced EDA segment regulates fibronectin-dependent cell cycle progression and mitogenic signal transduction. J Biol Chem 274: 5919-5924, 1999.

31. Ohnishi T, Hiraga S, Izumoto S, Matsumura H, Kanemura Y, Arita $\mathrm{N}$ and Hayakawa T: Role of fibronectin-stimulated tumor cell migration in glioma invasion in vivo: Clinical significance of fibronectin and fibronectin receptor expressed in human glioma tissues. Clin Exp Metastasis 16: 729-741, 1998.

32. Sakai T, Johnson KJ, Murozono M, Sakai K, Magnuson MA, Wieloch T, Cronberg T, Isshiki A, Erickson HP and Fässler R: Plasma fibronectin supports neuronal survival and reduces brain injury following transient focal cerebral ischemia but is not essential for skin-wound healing and hemostasis. Nat Med 7: 324-330, 2001

33. Moursi AM, Damsky CH, Lull J, Zimmerman D, Doty SB, Aota $S$ and Globus RK: Fibronectin regulates calvarial osteoblast differentiation. J Cell Sci 109: 1369-1380, 1996.

34. Johansson S, Svineng G, Wennerberg K, Armulik A and Lohikangas L: Fibronectin-integrin interactions. Front Biosci 2: d126-d146, 1997.

35. Sottile $\mathbf{J}$ and Hocking DC: Fibronectin polymerization regulates the composition and stability of extracellular matrix fibrils and cell-matrix adhesions. Mol Biol Cell 13: 3546-3559, 2002.

36. Goerges AL and Nugent MA: pH regulates vascular endothelial growth factor binding to fibronectin: A mechanism for control of extracellular matrix storage and release. J Biol Chem 279: 2307-2315, 2004.

37. Vannier C, Mock K, Brabletz T and Driever W: Zeb1 regulates E-cadherin and Epcam (epithelial cell adhesion molecule) expression to control cell behavior in early zebrafish development. J Biol Chem 288: 18643-18659, 2013.

38. Verschueren K, Remacle JE, Collart C, Kraft H, Baker BS, Tylzanowski P, Nelles L, Wuytens G, Su MT, Bodmer R, et al: SIP1, a novel zinc finger/homeodomain repressor, interacts with Smad proteins and binds to 5'-CACCT sequences in candidate target genes. J Biol Chem 274: 20489-20498, 1999.

39. Remacle JE, Kraft H, Lerchner W, Wuytens G, Collart C, Verschueren K, Smith JC and Huylebroeck D: New mode of DNA binding of multi-zinc finger transcription factors: deltaEF1 family members bind with two hands to two target sites. EMBO J 18: 5073-5084, 1999.

40. Francis NJ and Kingston RE: Mechanisms of transcriptional memory. Nat Rev Mol Cell Biol 2: 409-421, 2001.

41. Cao R, Wang L, Wang H, Xia L, Erdjument-Bromage H, Tempst $\mathrm{P}$, Jones RS and Zhang Y: Role of histone H3 lysine 27 methylation in Polycomb-group silencing. Science 298: 1039-1043, 2002.

42. Chang CJ and Hung MC: The role of EZH2 in tumour progression. Br J Cancer 106: 243-247, 2012.

43. Min J, Zaslavsky A, Fedele G, McLaughlin SK, Reczek EE, De Raedt T, Guney I, Strochlic DE, Macconaill LE, Beroukhim R, et al: An oncogene-tumor suppressor cascade drives metastatic prostate cancer by coordinately activating Ras and nuclear factor-kappaB. Nat Med 16: 286-294, 2010.

44. Bracken AP, Pasini D, Capra M, Prosperini E, Colli E and Helin K $\mathrm{EZH} 2$ is downstream of the $\mathrm{pRB}-\mathrm{E} 2 \mathrm{~F}$ pathway, essential for proliferation and amplified in cancer. EMBO J 22: 5323-5335, 2003.

45. Shi B, Liang J, Yang X, Wang Y, Zhao Y, Wu H, Sun L, Zhang Y, Chen Y, Li R, et al: Integration of estrogen and Wnt signaling circuits by the polycomb group protein EZH2 in breast cancer cells. Mol Cell Biol 27: 5105-5119, 2007.

46. Xu K, Wu ZJ, Groner AC, He HH, Cai C, Lis RT, Wu X, Stack EC, Loda M, Liu T, et al: EZH2 oncogenic activity in castrationresistant prostate cancer cells is Polycomb-independent. Science 338: 1465-1469, 2012

47. Lee ST, Li Z, Wu Z, Aau M, Guan P, Karuturi RK, Liou YC and $\mathrm{Yu}$ Q: Context-specific regulation of NF- $\kappa \mathrm{B}$ target gene expression by EZH2 in breast cancers. Mol Cell 43: 798-810, 2011.

48. Asangani IA, Ateeq B, Cao Q, Dodson L, Pandhi M, Kunju LP, Mehra R, Lonigro RJ, Siddiqui J, Palanisamy $\mathrm{N}$, et al: Characterization of the EZH2-MMSET histone methyltransferase regulatory axis in cancer. Mol Cell 49: 80-93, 2013.

49. Takeda K and Akira S: STAT family of transcription factors in cytokine-mediated biological responses. Cytokine Growth Factor Rev 11: 199-207, 2000.

50. Zhou P, Jiang W, Weghorst CM and Weinstein IB: Overexpression of cyclin D1 enhances gene amplification. Cancer Res 56: 36-39, 1996.

51. Arnold A and Papanikolaou A: Cyclin D1 in breast cancer pathogenesis. J Clin Oncol 23: 4215-4224, 2005.
52. Stylianou S, Clarke RB and Brennan K: Aberrant activation of notch signaling in human breast cancer. Cancer Res 66: $1517-1525,2006$.

53. Mungamuri SK, Yang X, Thor AD and Somasundaram K: Survival signaling by Notch1: Mammalian target of rapamycin (mTOR)-dependent inhibition of p53. Cancer Res 66: 4715-4724, 2006.

54. Lee CW, Simin K, Liu Q, Plescia J, Guha M, Khan A, Hsieh CC and Altieri DC: A functional Notch-survivin gene signature in basal breast cancer. Breast Cancer Res 10: R97, 2008.

55. Dickson BC, Mulligan AM, Zhang H, et al: High-level JAG mRNA and protein predict poor outcome in breast cancer. Mod Pathol 20: 685-693, 2007.

56. Calaf GM and Hei TK: Establishment of a radiation- and estrogen-induced breast cancer model. Carcinogenesis 21: 769-776, 2000.

57. Jagtap S, Meganathan K, Wagh V, Winkler J, Hescheler J and Sachinidis A: Chemoprotective mechanism of the natural compounds, epigallocatechin-3-O-gallate, quercetin and curcumin against cancer and cardiovascular diseases. Curr Med Chem 16: 1451-1462, 2009.

58. Calaf GM, Echiburú-Chau C, Wen G, Balajee AS and Roy D: Effect of curcumin on irradiated and estrogen-transformed human breast cell lines. Int J Oncol 40: 436-442, 2012.

59. Weissenberger J, Priester M, Bernreuther C, Rakel S, Glatzel M, Seifert V and Kögel D: Dietary curcumin attenuates glioma growth in a syngeneic mouse model by inhibition of the JAK1,2/ STAT3 signaling pathway. Clin Cancer Res 16: 5781-5795, 2010.

60. Calaf GM, Echiburú-Chau C, Roy D, Chai Y, Wen G and Balajee AS: Protective role of curcumin in oxidative stress of breast cells. Oncol Rep 26: 1029-1035, 2011.

61. Tiwari N, Gheldof A, Tatari M and Christofori G: EMT as the ultimate survival mechanism of cancer cells. Semin Cancer Biol 22: 194-207, 2012.

62. Mulholland DJ, Kobayashi N, Ruscetti M, Zhi A, Tran LM, Huang J, Gleave $\mathrm{M}$ and Wu H: Pten loss and RAS/MAPK activation cooperate to promote EMT and metastasis initiated from prostate cancer stem/progenitor cells. Cancer Res 72: 1878-1889, 2012.

63. Moreno-Bueno G, Portillo F and Cano A: Transcriptional regulation of cell polarity in EMT and cancer. Oncogene 27: 6958-6969, 2008.

64. Creighton CJ, Chang JC and Rosen JM: Epithelial-mesenchymal transition (EMT) in tumor-initiating cells and its clinical implications in breast cancer. J Mammary Gland Biol Neoplasia 15: 253-260, 2010

65. Vuoriluoto K, Haugen H, Kiviluoto S, Mpindi JP, Nevo J, Gjerdrum C, Tiron C, Lorens JB and Ivaska J: Vimentin regulates EMT induction by Slug and oncogenic $\mathrm{H}$-Ras and migration by governing Axl expression in breast cancer. Oncogene 30: $1436-1448,2011$

66. Hardy KM, Booth BW, Hendrix MJ, Salomon DS and Strizzi L: ErbB/EGF signaling and EMT in mammary development and breast cancer. J Mammary Gland Biol Neoplasia 15: 191-199, 2010.

67. Vincan $\mathrm{E}$ and Barker N: The upstream components of the Wnt signalling pathway in the dynamic EMT and MET associated with colorectal cancer progression. Clin Exp Metastasis 25: 657-663, 2008.

68. Javle MM, Gibbs JF, Iwata KK, Pak Y, Rutledge P, Yu J, Black JD, Tan D and Khoury T: Epithelial-mesenchymal transition (EMT) and activated extracellular signal-regulated kinase (p-Erk) in surgically resected pancreatic cancer. Ann Surg Oncol 14: 3527-3533, 2007.

69. Yin T, Wang C, Liu T, Zhao G and Zhou F: Implication of EMT induced by TGF-beta1 in pancreatic cancer. J Huazhong Univ Sci Technolog Med Sci 26: 700-702, 2006.

70. Pinho SS, Oliveira P, Cabral J, Carvalho S, Huntsman D, Gärtner F, Seruca R, Reis CA and Oliveira C: Loss and recovery of Mgat3 and GnT-III Mediated E-cadherin N-glycosylation is a mechanism involved in epithelial-mesenchymal-epithelial transitions. PLoS One 7: e33191, 2012.

71. Ivaska J: Vimentin: Central hub in EMT induction? Small GTPases 2: 51-53, 2011.

72. Wu Y and Zhou BP: Snail: More than EMT. Cell Adhes Migr 4: 199-203, 2010

73. Fendrich V, Waldmann J, Feldmann G, Schlosser K, König A, Ramaswamy A, Bartsch DK and Karakas E: Unique expression pattern of the EMT markers Snail, Twist and E-cadherin in benign and malignant parathyroid neoplasia. Eur J Endocrinol 160: 695-703, 2009. 
74. Mukhopadhyay A, Banerjee S, Stafford LJ, Xia C, Liu M and Aggarwal BB: Curcumin-induced suppression of cell proliferation correlates with down-regulation of cyclin D1 expression and CDK4-mediated retinoblastoma protein phosphorylation. Oncogene 21: 8852-8861, 2002.

75. Kumaravel M, Sankar P and Rukkumani R: Antiproliferative effect of an analog of curcumin bis-1,7-(2-hydroxyphenyl)-hepta1,6-diene-3,5-dione in human breast cancer cells. Eur Rev Med Pharmacol Sci 16: 1900-1907, 2012.
76. Lin SS, Lai KC, Hsu SC, Yang JS, Kuo CL, Lin JP, Ma YS, Wu CC and Chung JG: Curcumin inhibits the migration and invasion of human A549 lung cancer cells through the inhibition of matrix metalloproteinase-2 and -9 and vascular endothelial growth factor (VEGF). Cancer Lett 285: 127-133, 2009.

77. Huang T, Chen Z and Fang L: Curcumin inhibits LPS-induced EMT through downregulation of NF- $\kappa \mathrm{B}-$ Snail signaling in breast cancer cells. Oncol Rep 29: 117-124, 2013. 